\title{
The Sea as Respite: Challenging Dispossession and Re-Constructing Identity in the Interesting Narrative of the Life of Olaudah Equiano
}

\author{
Caitlin Simmons
}

This paper explores dispossession, identity formation, and spatial transformation in Olaudah Equiano's Interesting Narrative, a slave narrative and spiritual autobiography in which Equiano repeatedly traverses the Middle Passage initially under the control of slave owners, and later because he freely chooses to do so. As a self-emancipated slave who composes his own autobiographical travel narrative, Equiano hopes to accelerate the termination of England's slave trade by demonstrating through his text how a "savage" can reform into an educated, self-made Christian man. He spends over a decade of his life on ships and at port cities, crossing the Atlantic more than twice a year. Although this itinerant lifestyle is rooted in $18^{\text {th }}$ century circum-Atlantic slave trade networks, even after he gains his "freedom," Equiano consciously chooses to return to the sea, despite its inherent dangers in nautical exploration. I argue that by altering the sea into a strategic zone of agency, free from the legal constraints on land, Equiano overcomes his dispossession and heals his fractured identity.

In order to more clearly understand Equiano's plight as a slave on the Atlantic, I first utilize Judith Butler and Athena Athanasiou's notion of "dispossession" which they define broadly as "subjection to military, imperial, and economic violence," (2) and their assertion that it may be overcome through visibility. By putting their text in conversation with Doreen Massey's distinction between space as ever "under construction" and place as a more stable fixture, in addition to Margaret Cohen's detailed account of the sea's depiction in $18^{\text {th }}$ and $19^{\text {th }}$ century literature, the sea's dynamic role in Equiano's re-possession becomes evident. This paper is divided into two sections: the first will tackle dispossession, and the second will consider the sea as a constructed space for Equiano. Ultimately, I consider if choosing the sea is an act of effective and conscious displacement and if we can or should view Equiano's 


\section{IJCS}

choice to live at sea as a resistance to his relegation to the realm of the invisible. Can we view the sea as a site of transgression? I by no means intend to glorify the Middle Passage, or understate the horrors of the Atlantic slave trade. Nevertheless, I also see Equiano as a striking example of surmounting that same dispossession through his reclamation of the sea.

In the terms laid out by Butler and Athanasiou's Dispossession: The Performative in the Political, there are two types of dispossession: "in the first sense dispossession stands as a heteronomic condition," which means it places limits on the ideals of autonomy's "impermeable self-sufficiency" that have come to define the modern liberal subject (2). Each individual sacrifices personal autonomy in favor of adhering to and benefiting from the protection of the legal and other systems. We are all born into dispossession, which explains what both women mean by saying "we are already dispossessed" (5) when we come into being. We willingly sacrifice a part of our autonomy and subjectivity in order to endure in the world, even within the most common social interactions. Whereas virtually everyone falls into the first category of dispossession, albeit at varying levels of subjectivity, Equiano, when sold into slavery, is shorn of his very autonomy and cohesive identity. Treated as less than a person, he more closely resembles a $\operatorname{cog}$ in the endless machine of imperial capitalism - his captors have bestowed upon him "socially assigned disposability" (19) and determined that his "proper place is non-being." Equiano is a non-being who is not allowed to "take place." This second type of dispossession exemplified by Equiano describes "processes and ideologies by which persons are disowned...[through] loss of land and community; ownership of one's living body by another person, as in histories of slavery" (2). This type is more nefarious in its implementation of power; here, dispossession indicates "imposed injuries, painful interpellation, occlusions, and foreclosures [that are] painfully imposed by the normative and normalizing violence" (2). Not based in adherence to systems of legality or courtesy, this imposed violence is engineered to erase the identity, alterity and/or subjectivity of someone deemed "abnormal," "too different," or "less than." This becomes clear when Equiano no longer fears his captors, but instead desires to emulate them: "I no longer looked upon them as spirits, but as men superior to us; and therefore I had the stronger desire to resemble them; to imbibe their spirit, and imitate their manners" (78). It is the "imposition" that characterizes the difference between "being" dispossessed—-"at a fundamental level of subjection"-and "becoming" dispossessed — the "enforced deprivation of land, rights, livelihood, desire, or modes of belonging" (5). "Normalizing violence" steals Equiano from his family and dispossesses him from his unique subjectivity.

Removed from his home, and circumscribed to a sedentary life in London, (or any other land he inhabits), he is always owned, always less than, always more object than subject. He embodies what Butler and Athanasiou argue is a lack of "place" for the dispossessed. Even after earning and paying for his own freedom, an act that would ideally enable him to regain autonomy, he is robbed and threatened by Europeans and 
Americans alike. When his captain will not pay back the loan Equiano offers him, Equaino realizes the law will not allow him to recover it (161). After defending himself against a violent slave, Equiano then has to defend himself again when the slave's master threatens him. In a pivotal scene, he must hide on a docked ship to avoid violent retribution from the master. Equiano explains: "[I] thought I had better keep where I was, than go ashore and be flogged round the town, without judge or jury" (139). He is labeled free, but only when he is invisible, when he is not present. In this case, and the rest, he remains on the boat where he cannot be acknowledged, victimized or abused. The only space where Equiano can enjoy his freedom is at sea. Even after paying for his freedom, Equiano's uneasy position offers him no place of his own. Paradoxically, freedom offers even less coverage and protection under the law than when he was marked a slave. In moving out of his enslaved position, Equiano actually decreases his own agency. Butler and Athanasiou suggest that to overcome dispossession, one must either move to or within a place where one does not "belong" (displacement of the proper?) or remain exactly where one already is - in their "improper" place.

In Savannah, Georgia, some time later, white men choose not to beat Equiano because he "talked too good English" (177). He is an African demonstrating a comparative facility for English - and his persecutors do not know where to "place" him hierarchically. Equiano himself understands this dichotomy, recognizing that "there was little or no law for a free negro here" (159). Even though he has been fortunate enough to purchase his freedom from a previous master, he is denied a sense of belonging in America or England because of his obvious racial difference. While still referring to Africa as "my nation," Equiano experiences the same confusing dispossession. In London, he asks of his audience: "In this situation is it surprising that slaves, when mildly treated, should prefer even the misery of slavery to such mockery of freedom?" (138). He may be "free," but the word carries with it no genuine freedom, and thus, little to no value. Denied a place, can the dispossessed Equiano find freedom and establish a unified identity by inhabiting a typically uninhabitable space?

To Marxist and Cultural Geographer, Doreen Massey, the author of For Space, place is "meaningful, lived and everyday" whereas space is "outside? the abstract? the meaningless?" (Massey 6). In a later chapter, Massey explains the concept of space as contingent upon three main principles: space is "the product of interrelations," "the sphere of the possibility of the existence of multiplicity in the sense of contemporaneous plurality, [and is a zone] always under construction" (9). In other words, space not only encompasses, but transcends the boundaries of place, allowing for overlaps and interconnections that are ever changing and never definite. Place is a closed system with a determined future, whereas space allows genuine openness of the future (Massey 11) - not limited by the totemic temporality, nor placed in the language of progress (what kind of progress?). According to Massey, to have hope for future change, space must remain open, must allow for a multiplicity of trajectories (111) and simultaneous narratives. Whereas she focuses more exclusively on the 


\section{IJCS}

construction of spaces and places on land, I will use these definitions to further understand Equiano's potential for growth and mobility on and across the sea. To access the sea as an ever-evolving space, I pair Massey's text with Margaret Cohen's study of The Novel and the Sea, which elucidates themes of the ocean throughout the $18^{\text {th }}$ and $19^{\text {th }}$ centuries. Cohen cites the sea as a source of adventure novels from The Odyssey to Robinson Crusoe, similar to the adventurous voyages and shipwrecks conveyed throughout Equiano's narrative. Cohen argues that the sea functions as a space to carve out or uncover an identity for those who could not succeed on civilized land.

All of these elements are present in Equiano's exploration of the Middle Passage, but it is the life outside of morality or legal regulations that work to subconsciously entice him back to the ships. Cohen writes, "If virtue appears in sea fiction, it is as an afterthought. ...rather than civic or liberal freedom, the ruling freedom in sea fiction is the amoral freedom of movement corresponding to the juridical notion of the 'freedom of the seas" (11). Of particular significance in this passage are both the extra-legality of the sea and also the enhancement of unchecked mobility. She goes on: "Rather than a centripetal pull inward toward the metropolis and closure, [the sea offers] a centrifugal movement outward to the edges of the known world and beyond" (11). The sea is a place where boundaries and edges can be explored, challenged, negotiated, and sometimes even exceeded. Boundaries, rules, and systems do not apply. This extra-legality provides a space for Equiano to experience control, power, and agency. $\mathrm{He}$ earns numerous promotions, eventually being trusted enough to acquire navigational skills. On a journey to Georgia, after being freed, Equiano receives orders to lock up the slaves in the hold so that they cannot take up space on the rescue boat. He discloses to readers his thoughts on this horrific directive: "I could no longer restrain my emotion, and I told him he deserved drowning for not knowing how to navigate the vessel" (150). Not only does he say this to his captain, but to his white captain. He suffers no consequences and manages to save all of the slaves because the sea affords him this kind of unique authority — it adheres to its own law.

Others who inhabit the fringes of society also reclaim their autonomy by taking advantage of the sea's extra-legality. Perhaps the most poignant scene occurs when a mixed race couple that cannot be married on land because of their racial difference hosts a wedding a short distance into the water. Equiano describes it:

A very curious imposition on human nature took place:-A white man wanted to marry in the church a free black woman: but the clergyman told him it was against the law of the place to marry a white and a black in the church. The man then asked to be married on the water, to which the parson consented, and the two lovers went in one boat, and the parson and clerk in another, and thus the ceremony was performed. After this the loving pair came on board our vessel, and my captain treated them extremely well. (119, my emphasis) 
That is no problem for the couple - they move beyond this encumbrance by moving the ceremony to an uncharted, ever-constructing space, rather than remaining in a settled place. The moment is one in which a mixed race couple - a "phenomenon" at the time - is able to exist without suffering the ramifications of their dispossession. They are equal and free when they inhabit a part of the world that cannot be contained by - and is not subject to - the laws of place. Yet, presumably when they are brought back to land, the same struggles they faced prior to marriage will begin to have negative consequences once again. The marriage occurs both outside of the legality enforced on land, and also on the abstract edges of society. The law stops, but the sea enables.

According to Cohen, the sea consistently acts as a bridge to connect across difference (101) and (for mariners) acts in the interest of transgressing limits (112). The sea is fluid. It is, by virtue of this fluidity, capable of championing numerous perspectives, legacies, and narratives, while exacting change, inspiring loyalty, and even love. It is ever reforming, re-establishing and re-defining itself. It is quite literally a reality that is constantly moving, always shifting its perspectives, its shape and its dimensions. It can be embraced in the moment as a place for those exiled to or desirous of its undefined vastness, but at the core of its being, it is emblematic of Massey's definition and classification of space as ever "under construction." Therein lies its uncertainty and its value. As Equiano is denied the comfort of a "home," "secure retreat," or a "patch of land" to defend, the sea suits the realities of his existence more comfortably than any space or place he has temporarily inhabited. This sense of personal agency and identity is the draw that repeatedly pulls Equiano back. His embrace of the liminal space of the sea is a conscious act against dispossession - an expression of free will and freedom.

In both the marriage at sea and Equiano's repeated and conscious choice to return to the ocean, "displacement of the proper" characterizes a space that cannot be regulated or dominated by man - one which exists only on the fray of law-bound society and defies the jurisdiction of any man-made laws. It is a sanctuary that supplants and evades the petty weaknesses and fears of land-bound conformists. The laws of the sea, however, while guaranteeing a freedom of place not enjoyed on land by the dispossessed, do not provide the same assurances when the space is subject to the laws of the land. The sea constitutes altered space, but it is a space without an owner. Power has not shifted, nor has "visibility" been fully granted. Yet, Equiano has displaced the proper by altering the space. There is also something to be said for Equiano embracing and finding a location for his hybrid identity without sacrificing either element of it, which he could have easily done to appease the Europeans and Americans who were so often the source of his dispossession. Ultimately, the sea affords more than just freedom from the land-sodden rules of $18^{\text {th }}$ century empire; it is a respite from the forces of disenfranchisement - a space of action, assertion, and arrival, a place of progress and power, but one not without its limitations. 
80 IJCS

Works Cited

Balogun, F. Odun. "Self and Place in African and African-American Autobiographical Prose:

Equiano and Achebe, Soyinka and Gates." Sacred Spaces and Public Quarrels: African Culture and Economic Landscapes, edited by Paul Tiyambe Zeleza and Ezekiel Kalipeni, Africa World Press, 1999: 197-232. Print.

Ben-zvi, Yael. "Jacob in Olaudah Equiano's The Interesting Narrative." The Explicator 70.2 (2012): 108-111. Print.

Bohls, Elizabeth. Slavery and the Politics of Place: Representing the Colonial Caribbean, 1770-1833. Cambridge: Cambridge University Press, 2014. Print

Bozeman, Terry S. "Interstices, Hybridity, and Identity: Olaudah Equiano and the Discourse of the African Slave Trade." Studies in the Literary Imagination 36.2 (2003): 61-70.

Butler, Judith and Athena Athanasiou. Dispossession: The Performative in the Political. Cambridge: Polity Press, 2013. Print.

Carretta, Vincent. Equiano, The African: Biography of a Self-Made Man. Athens, Georgia: University of Georgia Press, 2005. Print

Carretta, Vincent, and Philip Gould. Genius in Bondage: Literature of the Early Black Atlantic. Lexington: University of Kentucky, 2001. Print.

Cohen, Margaret. The Novel and the Sea. Princeton, New Jersey: Princeton University Press, 2013. Print.

Collins, Janelle. "Passage to Slavery, Passage to Freedom: Olaudah Equiano and the Sea." The Midwest Quarterly 47.3 (2006): 209-23. Print.

Mallipeddi, Ramesh. Spectacular Suffering: Witnessing Slavery in the EighteenthCentury British Atlantic. Charlottesville: University of Virginia Press, 2016. Print.

Massey, Doreen. for space. London: Sage Publishing, 2005. Print.

Morrison, James V. Shipwrecked: Disaster and Transformation in Homer, Shakespeare, Defoe, and the Modern World. Ann Arbor: University of Michigan Press, 2014. Print.

Rediker, Marcus. The Slave Ship: A Human History. London: Viking Penguin, 2007. Print.

Thompson, Carl, editor. Shipwreck in Art and Literature: Images and Interpretations from Antiquity to the Present Day. New York: Routledge, 2014. Print. 